Reprod. Nutr. Dévelop., 1987, 27 (4), 791-799.

\title{
Preovulatory injection of estradiol-17 $\beta$ : effect on noradrenaline activity in different parts of the rabbit oviduct
}

\author{
F. BERNET, M. VERLEYE, A. SACHY
}

Laboratoire de Neurophysiologie et Neurobiologie, U.A. 308, C.N.R.S., Université des Sciences et Techniques de Lille-Flandres Artois,

59655 Villeneuve d'Ascq Cedex, France.

Summary. This paper compares noradrenaline content in the different parts of the oviduct in rabbits receiving or not a dose of estradiol-17 $\beta 24 \mathrm{~h}$ before human chorionic gonadotropin (HCG) and killed $60 \mathrm{~h}$ post HCG. 3,4-Dihydroxyphenylalanine assays were carried out in the oviduct after aromatic L-amino acid decarboxylase was inhibited by $\mathrm{m}$ hydroxybenzylhydrazine (NSD 1015) in the same experimental conditions.

Pauerstein et al. (1974) have shown that an intramuscular injection of $250 \mu \mathrm{g}$ of estradiol-17 $\beta$ in rabbits $24 \mathrm{~h}$ before intravenous injection of $100 \mathrm{IU}$ of HCG delays ovum transport at the ampullary-isthmic junction. The extent of this noradrenergic innervation suggested that estradiol could act at least partially through the noradrenergic systems.

Our results show that estradiol-17 $\beta$ increased oviduct weight by water retention without modifying either the tyrosine hydroxylase activity or the noradrenaline content in any part of the oviduct and that, consequently, the estrogen-induced " tube locking " of ova was not mediated through the noradrenergic processes.

\section{Introduction.}

Oestrous rabbits ovulate within 10 to $12 \mathrm{~h}$ after the injection of human chorionic gonadotropin (HCG) or mating (Harper, 1963). The ova are transported to the ampullary-isthmic junction within 10 min of ovulation, where they remain for at least $24 \mathrm{~h}$ after HCG or copulation (Pauerstein et al., 1974; Tsutsumi and Hafez, 1974). They move slowly through the median isthmus some $60 \mathrm{~h}$ post HCG or post coitum. Two regions of the oviduct seem to be involved in regulating the transport of ova into the uterus : the ampullary-isthmic junction (AIJ) and the tubal uterine junction (TUJ) (Blair and Beck, 1976).

Pauerstein et al. (1974) showed that an injection of estradiol-17 $\beta\left(E_{2}\right) 24 \mathrm{~h}$ prior to HCG injection delayed ovum transport at the AlJ until $72 \mathrm{~h}$ post HCG. According to these authors, sexual steroids could act at least partially on the tubal transport of ova by means of the noradrenergic system. The extent of AlJ 
noradrenergic innervation (Brundin and Wirsen, 1964), and the fact that tubal motility is stimulated by $\alpha$-adrenergic agonists and blocked by $\alpha$-antagonists (see review of Paton et al., 1978), argue in favour of this hypothesis.

Considering the extent of AIJ noradrenergic innervation and its apparent part in ovum transport, we compared the noradrenaline (NA) content in different parts of the oviduct in rabbits receiving or not a dose of $E_{2} 24 \mathrm{~h}$ before $\mathrm{HCG}$ and sacrificed $60 \mathrm{~h}$ after HCG stimulation. At that time, all the ova were present in the median isthmus of rabbits treated with HCG only, whereas they were delayed at the AIJ in those treated with $E_{2}$ plus HCG. It was thought that the AlJ of the controis was relaxed, while in treated animals it was still contracted. It seemed that a comparison of the oviductal parts at that time would facilitate the observation of any differences. To obtain an index of dynamic noradrenergic activity in the oviduct, we measured tyrosine hydroxylase (TH) activity in vivo by quantifying the accumulation of dihydroxyphenylalanine (DOPA), a precursor of NA, after the inhibition of aromatic L-amino acid decarboxylase by $\mathrm{m}$ hydroxybenzylhydrazine (NSD 1015) in the same experimental conditions.

\section{Material and methods.}

1) Animals. Twenty sexually mature female rabbits weighing 2 to $3 \mathrm{~kg}$ were used. They were put two in a cage under controlled light (12L:12D) and received water and food ad libitum.

2) Experimental conditions. Ovulation was induced by an intravenous injection of 100 IU of HCG (Distrivet, Roussel Uclaf).

Four groups of five animals each were constituted. Groups 1 and 2 were used for NA measurement and groups 3 and 4 for the measurement of DOPA accumulation after inhibition of aromatic L-amino acid decarboxylase by NSD 1015 (Sigma). The animals of groups 1 and 3 received HCG only and those of groups 2 and 4 were injected intramuscularly with a single dose of $250 \mu \mathrm{g}$ of depoestradiol (estradiol-17 $\beta$ cypionate, Sigma) $24 \mathrm{~h}$ prior to HCG. The estradiol$17 \beta$ was dissolved in $0.2 \mathrm{ml}$ of olive oil.

The rabbits of groups 3 and 4 were injected intravenously with NSD 1015 $(200 \mathrm{mg} / \mathrm{kg}) 30 \mathrm{~min}$ before sacrifice. All were sacrificed at $60 \mathrm{~h}$ post HCG.

Preparation of oviductal parts. - Each oviduct was excised, placed in an icecooled dish, and rapidly dissected of adipose and connective tissue.

The oviduct was eventually divided into four parts. It was first separated into two equal portions, the first near the ovary being the infundibular-ampullar region (IA). The second portion was then divided into three parts of equal length : the ampullary-isthmic junction, the median isthmus (MI) and the utero-tubal junction near the uterus.

These four parts were frozen in isopentane at $-160^{\circ} \mathrm{C}$. Following this rapid freezing $(15 \mathrm{~s})$, the parts were stored in a refrigerator at $-20^{\circ} \mathrm{C}$ until biochemical assay. 


\section{3) Biochemical analysis.}

Separation and measurement of NA. - The tissues were homogenized in an iced ground-glass tissue grinder with $400 \mu \mathrm{l}$ of $0.2 \mathrm{M}$ perchloric acid (or ten volumes for the larger samples) containing $0.05 \mathrm{M}$ ascorbic acid and $50 \mu \mathrm{l}$ of $10^{-6}$ dihydroxybenzylamine (DHBA) as the internal standard. The homogenate was centrifuged at $22000 \times \mathrm{g}$ at $4{ }^{\circ} \mathrm{C}$ for $15 \mathrm{~min}$.

Twenty microliters of the supernatant were injected into the highperformance liquid chromatograph (HPLC) coupled with electrochemical detection. The HPLC apparatus was a Beckman model 340 isocratic liquid chromatograph equipped with a model 112 pump and a $5-\mu$ ultrasphere ODS analytical column (Beckman) $15 \mathrm{~cm}$ long $\times 4.6 \mathrm{~mm}$ i.d. The mobile phase was the solvent system used by Mefford (1981) for separating catecholamines. It contained $0.1 \mathrm{M}$ sodium acetate, $0.02 \mathrm{M}$ sodium citric acid, $100 \mathrm{mg} / \mathrm{l}$ of sodium octysulfate, $50 \mathrm{mg} / \mathrm{l}$ of EDTA and $12 \%$ of methanol $(\mathrm{v} / \mathrm{v})$. The mobile phase was filtered through a $0.45-\mu \mathrm{m}$ filter (Millipore) and degassed under vacuum before use. A flow rate of $1.0 \mathrm{ml} / \mathrm{min}$ at ambient temperature was employed.

The electrochemical detector included a Tacussel-type PRG/DEL amperometric unit and a chromatofield type EC3 electrochemical cell equipped with a glassy carbon electrode set at a potential of $+0.60 \mathrm{~V}$ relative to an $\mathrm{Ag} / \mathrm{AgCl}$ reference electrode. The oxidation current, which was directly proportional to the concentration of NA passing by the electrode, was monitored on a strip-chart recorder (type BD 40, Kipp and Zonen).

The amounts of NA in a sample were determined by measuring peak heights and comparing these directly with external standards that were run each day. The recovery of the extraction procedure was taken into account and calculated from the difference between the values of the added internal standard in tissues and the values for the same standard assayed directly. All results were corrected for recovery loss.

Separation and measurement of DOPA. - The sample preparation was the same but $10^{-3} \mathrm{mg} \cdot \mathrm{ml}^{-1}$ adrenaline was taken for DHBA as the internal standard because DHBA was eluted with DOPA.

We used the mobile phase for the separation of DOPA reported by Brokaw, Hansen and Christie (1985). It consisted of two parts $0.02 \mathrm{M}$ citric acid, one part $0.02 \mathrm{M}$ sodium phosphate, $5 \times 10^{-5}$ EDTA, $0.1 \mathrm{mM}$ octane sulfonate and $1.5 \%$ methanol and was pumped through the system at a rate of $2.3 \mathrm{ml} / \mathrm{min}$. The working electrode was set at $+0.72 \mathrm{~V} v s$ the reference electrode.

Protein assay. - After centrifugation of the tissue samples, the supernatant was analysed by HPLC-EC and the protein content of the pellet was determined by the method of Miller (1959).

4) Statistical analysis. - Group means were compared using Student's t-test. 


\section{Results.}

\section{Groups 1 and 2 (NA measurement)}

Oviduct weight variation. - Pretreatment by estrogen increased oviduct weight : $191.7 \pm 58.4 \mathrm{mg}$ (mean $\pm S E$ ) in the $E_{2}+$ HCG-treated rabbits $v s$ $142.7 \pm 42.0 \mathrm{mg}$ (mean $\pm \mathrm{SE}$ ) in the $\mathrm{HCG}$-treated rabbits $(\mathrm{t}=2.1 ; \mathrm{P}<0.05)$; the difference between these two groups for each part of the oviduct was significant for the IA and $\mathrm{MI}$ parts (fig. 1).

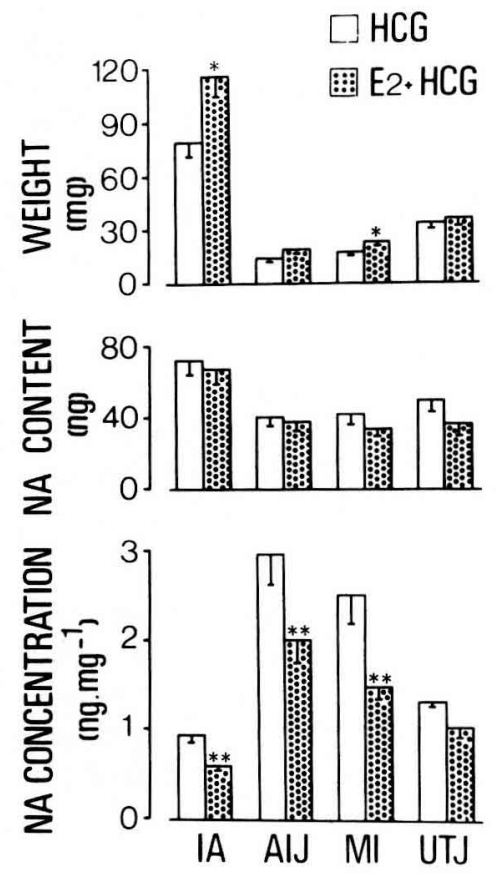

FIG. 1. - Weight of the oviductal portions, noradrenaline (NA) content and NA concentration in the different parts of the oviduct in HCG-treated rabbits (HCG) and in estradiol- $17 \beta$ olus HCG-treated rabbits $\left(\mathrm{E}_{2}+\mathrm{HCG}\right)$. The mean values are indicated with the standard error of the mean.

${ }^{*} \mathrm{P}<.05,{ }^{*} \mathrm{P}<.01$, compared with HCG-treated rabbits.

NA content and concentration in different oviductal parts. - There was no difference between the two groups as to the NA content in the different parts of the oviduct (fig. 1). Estrogen pretreatment did not modify the oviduct NA content measured in HCG-treated rabbits.

On the other hand, the concentration, that is the NA content per unit of organ weight (fig. 1), was significantly lower in the $|A, A| J$ and $M \mid$ parts in $E_{2}+$ HCG-treated rabbits $(P<0.01)$.

Protein content and NA concentration expressed as NA content per mg of protein in different oviductal parts (table 1). - There was no significant difference between the two groups, and the injection of a single dose of estrogen did not modify either the protein content or the NA concentration, expressed as the NA 


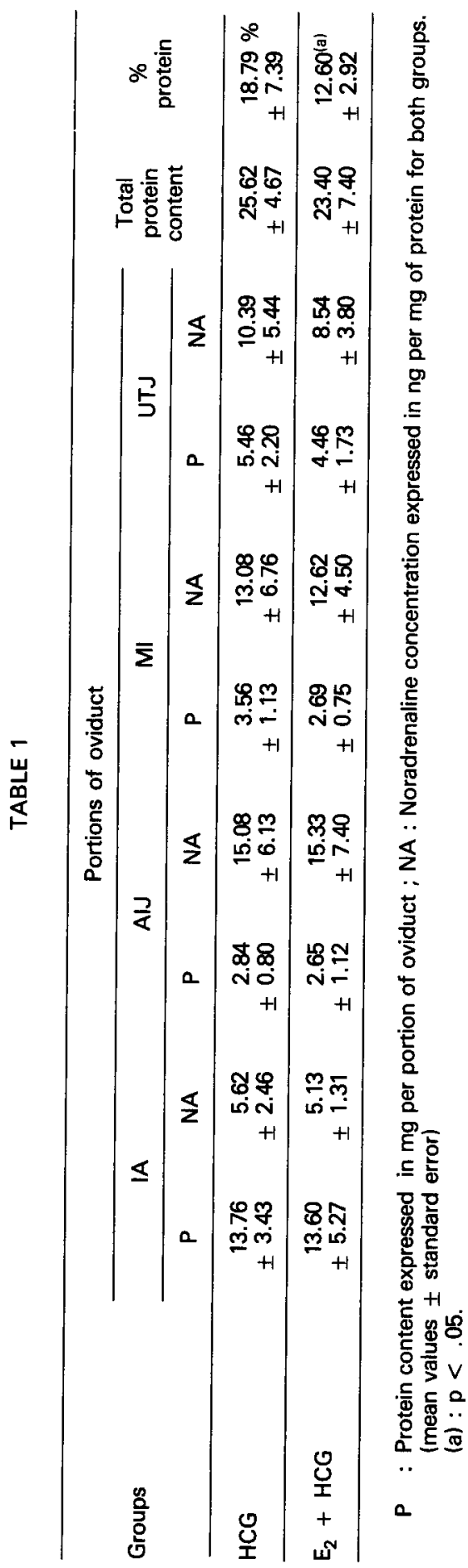


content per mg of protein, in any part of the oviduct of HCG-treated rabbits. Only the percentage of protein in these rabbits was higher than that of the $E_{2}+\mathrm{HCG}$ treated rabbits : $18.79 \pm 7.39 \%$ vs $12.60 \pm 2.92 \%(t=2.42 ; \mathrm{P}<0.05)$.

Comparison of NA concentration in different oviductal parts. - In both groups, the AlJ part showed a significantly higher concentration of NA than the IA and UTJ parts $(P<0.001)$. The difference between the AIJ and MI parts was significant only for group 2 ( $t=2.5 ; P<0.05$ ).

Groups 3 and 4 (DOPA measurement).

Oviduct weight variation. - As in groups 1 and 2, estrogen pretreatment induced a significant increase in the weight of all parts (fig. 2).

DOPA content and concentration in different oviductal parts. - The DOPA content in each oviductal part in the HCG-treated animals was identical to that of the corresponding part in the $E_{2}+H C G$-treated animals (fig. 2). Estrogen pretreatment did not modify the oviductal content of DOPA measured in HCGtreated rabbits.

On the other hand, the concentration of DOPA, expressed in ng of DOPA per $\mathrm{mg}$ of oviduct tissue, was significantly higher in the four oviduct parts of HCG-treated rabbits than in the corresponding parts of $E_{2}+$ HCG-treated animals.

Comparison of DOPA concentrations in different oviductal parts. - As in the case of NA concentration, the DOPA concentration of the AlJ significantly exceeded that of the other three parts in HCG-treated rabbits $4 \mathrm{t}=3.57$; $P<0.01$.
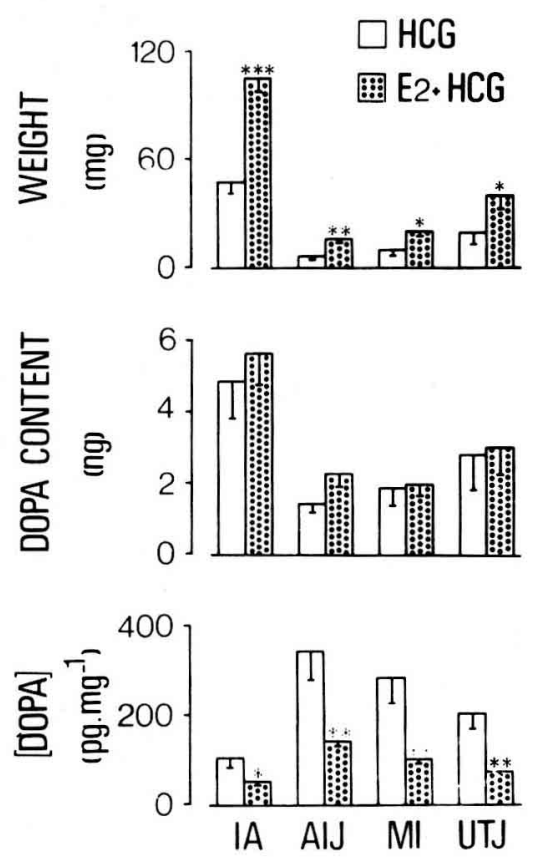

FIG. 2. - Weight of the oviductal portions, DOPA content and DOPA concentration in the different parts of the oviduct in HCG-treated rabbits (HCG) and in estradiol-17ß plus HCG-treated rabbits $\left(E_{2}+H C G\right)$.

The mean values are indicated with the standard error of the mean.

${ }^{*} \mathrm{P}<.05,{ }^{*} \mathrm{P}<.01,{ }^{* * *} \mathrm{P}<.001$, compared with HCG-treated rabbits. 


\section{Discussion.}

These results agree with the first observations of Brundin (1965) who noted a difference of NA concentration between the IA and the other half of the oviduct. Our measurements carried out in smaller isthmus portions allowed us to specify these differences. The NA concentration was highest in the AIJ. This concentration then gradually decreased up to the uterus. In a previous study, Bodkhe and Harper (1972) revealed that the NA concentration in the distal isthmus near the ampulla was much higher than in the proximal isthmus near the uterus.

In the same way, tyrosine hydroxylase activity, evaluated by the accumulation of DOPA following inhibition of aromatic L-amino acid decarboxylase, was at a maximum in the AlJ and decreased up to the uterus. These quantitative data confirm the qualitative histochemical observations of Brundin (1965), Sjöberg (1967) and Black (1974). According to these authors, adrenergic nerve supply to the infundibulum and the ampulla is reduced and mainly located in the perivascular areas, while the circular muscle layer of the isthmus is abundantly penetrated by varicose adrenergic nerve terminals. Our results emphasize the importance of the AlJ which showed higher noradrenergic innervation than the utero-tubal junction often compared with it.

The injection of a single dose of $250 \mu \mathrm{g}$ of depo-estradiol $24 \mathrm{~h}$ before HCG primarily led to an enhanced oviduct weight without modifying either the TH activity or NA content in any oviductal part. The amount of total protein also remained stable while its percentage decreased significantly. Only increased water retention could account for oviduct weight gain following treatment with exogenous $E_{2}$. These observations are supported by the works of Hudgson (1978) and Overström, Bigsby and Black (1980) who reported that exogenous $E_{2}$ enhanced tissue fluid uptake and tissue water content in the rabbit oviduct. According to these authors, the oviductal oedema induced by a preovulatory $E_{2}$ surge would temporarily block ovum transport at the AIJ, isthmus and UTJ.

Our data suggest that the estrogen-induced " tube locking " of ova is not mediated through noradrenergic processes. In the same way, Eddy and Black (1974) showed that chemical denervation by local application of 6hydroxydopamine does not disrupt normal egg transport nor egg implantation in the uterus. Recently, Roche, Parkington and Gibson (1985) proved that surgical denervation does not affect tubal transport of ova. Nevertheless, some results like those of Hodgson, Fremming and Daly (1975) are inconsistent with these data. These authors succeeded in decreasing the average number of egg implantations in the uterus by introducing 6-hydroxydopamine into the oviduct. However the unchanged NA content and TH activity in the oviducts of rabbits receiving a pharmacological dose of estrogen $24 \mathrm{~h}$ before HCG does not entirely exclude the mediation of noradrenergic systems in delayed ovum passage. The number or the affinity of adrenergic receptors within the oviductal smooth muscle and in the uterine myometrium (Hoffman et al., 1981) might be increased by $E_{2}$, and this could lead to modified muscular activity in the most innervated part, i.e. in the AlJ. Further research is required to determine other neuronal systems, such as cholinergic 
or peptidergic neurons, implicated in ovum transport. Helm et al. (1985) have assumed that vasoactive intestinal polypeptide (VIP) present in the oviduct might be involved in the complex mechanism of ovum transport. These authors have always shown that the spontaneous contractile activity of oviductal musculature is inhibited by exposure to exogenous VIP. This observation may be approximated to the previous study of Hodgson and Talo (1978) who showed in vitro that the frequency of oviductal EMG activity decreased $68 \mathrm{~h}$ after $\mathrm{HCG}+\mathrm{E}_{2}$ injection during ovum "tube locking ". The estrogen-induced "tube locking " of ova could be explained by the inhibition of EMG activity in the isthmus and AIJ.

Our results emphasize the extent of oviduct noradrenergic innervation at the ampullary-isthmic junction, but they do not confirm the hypothesis that noradrenergic mechanisms might lead to retarded ovum transport in rabbits when a large dose of estrogen is given. Only a study of adrenergic receptors will allow a definite answer to this question.

Reçu en novembre 1986. Accepté en mars 1987.

Acknowledgments. - The authors wish to thank Professor J.-P. Rousseau for his helpful suggestions and discussion.

Résume. Effet d'une injection préovulatoire de 17\%-cstradiol sur l'activité noradrénergique des différentes portions de l'oviducte chez la lapine.

Pour vérifier l'hypothèse selon laquelle les systèmes noradrénergiques sont impliqués dans le retard de migration des œufs induit par injection de $17 \beta$-œstradiol, nous avons comparé la teneur en noradrénaline dans les différentes portions de l'oviducte chez des lapines ayant reçu ou non une injection de $17 \beta$-œstradiol $24 \mathrm{~h}$ avant I'HCG et sacrifiées $60 \mathrm{~h}$ après le stimulus ovulatoire. Parallèlement, des dosages de la 3,4-dihydroxyphénylalanine, précurseur de la noradrénaline, ont été effectués dans l'oviducte après blocage par le NSD 1015, inhibiteur de la décarboxylase des amino-acides aromatiques, pour mesurer l'activité de la tyrosine hydroxylase dans les mêmes conditions expérimentales.

Le 17 $\beta$-œstradiol n'a modifié ni la quantité globale de noradrénaline ni l'activité de la tyrosine hydroxylase des oviductes mais a entraîné une augmentation de leur poids par rétention d'eau. II paraît donc difficile d'établir une corrélation entre le retard de migration des ovocytes provoqué par le $17 \beta$-œstradiol et une modification de l'activité des systèmes noradrénergiques.

\section{References}

BLACK D. L., 1974. Neural control of oviduct musculature, 66-118. In JOHNSON A. D., FOLEY C. W., The oviduct and its functions, Acad. Press Inc., New York.

BLAIR W. D., BECK L. R., 1976. Demonstration of postovulatory sphincter action by the isthmus of the rabbit oviduct. Fertil. Steril., 27, 431-441.

BODKHE R. R., HARPER M. J. K., 1972. Changes in the amount of adrenergic neurotransmitter in the genital tract of untreated rabbits, and rabbits given reserpine or iproniazid during the time of egg transport. Biol. Reprod., 6, 288-299. 
BROKAW J. J., HANSEN J. T., CHRISTIE D. S., 1985. The effects of hypoxia on catecholamine dynamics in the rat carotid body. J. aut. Nerv. Syst., 13, 35-47.

BRUNDIN J., 1965. Distribution and function of adrenergic nerves in the rabbit Fallopian tube. Acta physiol. scand., 66, suppl. 259, 5-52.

BRUNDIN J., WIRSEN C., 1964. Adrenergic nerve terminals in the human Fallopian tube examined by fluorescence microscopy. Acta physiol. scand., 61, 505-506.

EDDY C. A., BLACK D. L., 1974. Ovum transport through rabbit oviducts perfused with 6-hydroxydopamine. J. Reprod. Fertil., 33, 1-9.

HARPER M. J. K., 1963. Ovulation in the rabbit : the time of follicular rupture and expulsion of the eggs, in relation to injection of luteinizing hormone. J. Endocr., 26, 307-316.

HELM G., EKMAN R., RYDHSTOM H., SJOBERG N. O., WALLES B., 1985. Changes in oviductal VIP content induced by sex steroids and inhibitory effect of VIP on spontaneous oviductal contractility. Acta physiol. scand., 125, 219-224.

HODGSON B. J., 1978. Post-ovulatory changes in the water content and inulin space of the rabbit oviduct. J. Reprod. Fert., 53, 349-351.

HODGSON B. J., FREMMING B. D., DALY S., 1975. Effects of adrenergic drugs administered during ovum transport and chemical sympathectomy of the oviduct on fertility in rabbits. Biol. Reprod., 13, 142-146.

HODGSON B. J., TALO A., 1978. Spike bursts in rabbit oviduct. II. Effects of estrogen and progesterone. Amer. J. Physiol., 234, E439-E443.

HOFFMAN B. B., LAVIN T. H., LEFKOWITZ R. J., RUFOLO R. R., 1981. Alpha-adrenergic receptor subtypes in rabbit uterus : mediation of myometrial contraction and regulation by estrogens. J. Pharmac. exp. Ther., 219, 290-295.

MEFFORD I. N., 1981. Application of high performance liquid chromatography with electrochemical detection to neurochemical analysis : measurement of catecholamines, serotonin and metabolites in rat brain. J. Neurosci. Meth., 3, 207-224.

MILLER G. L., 1959. Protein determination for large number of samples. Analyt. Chem., 31, 964.

OVERSTRÖM E. W., BIGSBY R. M., BLACK D. L., 1980. Effects of physiological levels of estradiol-17 $\beta$ and progesterone on oviduct edema and ovum transport in the rabbit. Biol. Reprod., 23, 100-110.

PATON D. M., WIDDICOMBE J. H., RHEAUME D. E., JOHNS A., 1978. The role of the adrenergic innervation of the oviduct in the regulation of mammalian ovum transport. Pharmacol. Rev., 29, 67-102.

PAUERSTEIN C. J., ANDERSON V., CHATKOFF M. L., HODGSON B. J., 1974. Effect of oestrogen and progesterone on the time course of tubal ovum transport in rabbits. Am. J. Obstet. Gynec., 120, 299-308.

ROCHE P. J., PARKINGTON H. C., GIBSON W. R., 1985. Pregnancy and parturition in rats after sympathetic denervation of the ovary, oviduct and utero-tubal junction. J. Reprod. Fert., 75 , 653-661.

SJÖBERG N. O., 1967. The adrenergic transmitter of the female reproductive tract : distribution and functional changes. Acta physiol. scand., suppl. 305, 1-32.

TSUTSUMI Y., HAFEZ E. S. E., 1974. Distribution patterns of rabbit embryos during preimplantation stage. J. Morph., 144, 323-336. 